DOI: 10.2478/v10141-009-0029-6

\title{
Can We Talk about European Public Policy in the Field of Sport?
}

\section{Gyöngyi Szabó Földesi}

Semmelweis University, Faculty of Physical Education and Sport Science, Budapest, Hungary

KEYWORDS European public policy of sport, content, social competence, coercive factor, normative orientation

\section{Introduction}

From an analytical point of view, a policy can be defined according to the experience and rules originating from one or more public actors. In the field of sport these are the associations and the sport 
federations, the International Olympic Committee and - in certain countries - the National Olympic Committee, Ministries, European and international organisations etc.

In the last few years many studies have been published which seek to investigate the influence of European sport on sport world-wide. Unfortunately political scientists have neglected sport and failed to study it more carefully, in spite of its growing economic and social importance, which deserves much more attention, and as a result of this, there are no relevant empirical data.

On the other hand, the sport movement is largely attached to its own rules historically, thus protecting its autonomy and preserving its particularity and its own world. As was thought for a long time, this autonomy was to serve as a protection against national norms and the influence of the European Union.

The social, economic and cultural importance of sport is well-known in Europe ${ }^{1}$. Nevertheless, sport is also confronted with new threats and challenges which have emerged in European society, such as commercial pressure, exploitation of young players, doping, racism, violence, corruption and money-laundering. That is why politics is becoming increasingly interested in it. Accordingly, in the recent past, the various institutions of the European Union have come to pay more attention to sport issues. An important milestone of this was the European Commission issuing a White Paper on sport, and the inclusion of sport in the Lisbon Treaty. The European Court of Justice has dealt with sporting matters in landmark cases on several occasions since 1974, which also had obligatory influences on policy and the EU institutions.

However, the question arises: can we talk about a European public policy in the field of sport? The objective of the present article is to investigate this question.

\section{Public policy in the European Union}

During the analysis of this subject we have to face some practical difficulties relating to the fact that the European Construction and its architecture differs from those of its member states. At the same time, the concept and the theory of the political science seem to be quite difficult to apply at this level as well.

How can we explain the public authority at European level? Europe and its institutions are under continuous development and change, even though the outcome of these processes is much less known: federal or confederal state, supra-or international organisation with or without a constitution?

There is more or less solid agreement among political and social scientists as to what the nature and framework of the public policy should be and how it should be defined, as is stated by Yves Mény and Jean-Claude Thoening (1989) in their work Politiques Publiques. We can talk about public policy of a certain area if it corresponds to the following five criteria: content, social competence, the coercion factor, normative direction and programme.

\section{Sport in the EU}

To correctly answer the question of whether we can talk about a European public policy in the field of sport or not, first of all we have to define the content, namely the concept of "European sport".

\footnotetext{
${ }^{1}$ «Sport is a growing social and economic phenomenon which makes an important contribution to the European Union's strategic objectives of solidarity and prosperity. » (White Paper On Sport 2007)
} 
First of all we have to clarify the framework of our subject: are we talking about the European Union or perhaps about a larger unit including the member states of the Council of Europe as well? However, the "concept of Europe" in Western Europe differs largely from the concept of how we define Europe in Central and-Eastern Europe. In the common language, for western Europeans, Europe means the Union, most typically the founder members. Thus we can say that for them it is a political, rather than a geographical or cultural community. Even so, the Council of Europe has 47 member states, and they consider themselves European as well, which is reasonable. So what should be the starting point? Can it be the origin of sport associations' organisations? In this case we have to talk about non-independent countries such as Scotland, Wales, or non-European countries like Israel as well.

From a political point of view, the concept of «European sport» can be approached on the whole within the framework of the Council of Europe. Firstly, as all EU countries, which meet the other criteria more willingly, are also members of the Council of Europe. Secondly, since the Council of Europe is the oldest international, regional organization dealing with questions of sport at a political level as well.

The only official definition of sport can be found in Article 2 of the European Sports Charter issued by the Council of Europe: sport "means all forms of physical activity which, through casual or organised participation, aim at expressing or improving physical fitness and mental well-being, forming social relationships or obtaining results in competition at all levels." (European Sports Charter 1992, 2001)

The public policy is defined by its effect on people, on their situation, their interests and their behaviour. We have data only from the European Union concerning the sporting activity and behaviour of European citizens. The survey was requested by Directorate General Education and Culture and coordinated by Directorate General Press and Communication and was published in November 2004.

From a social point of view, either for money or for pleasure, regularly or occasionally, according to a November 2004 Eurobarometer survey (Citizens of the European Union and Sport 2004), approximately $38 \%$ of citizens throughout the 25 member States of the Union declare that they do sport at least once a week (Figure 1).

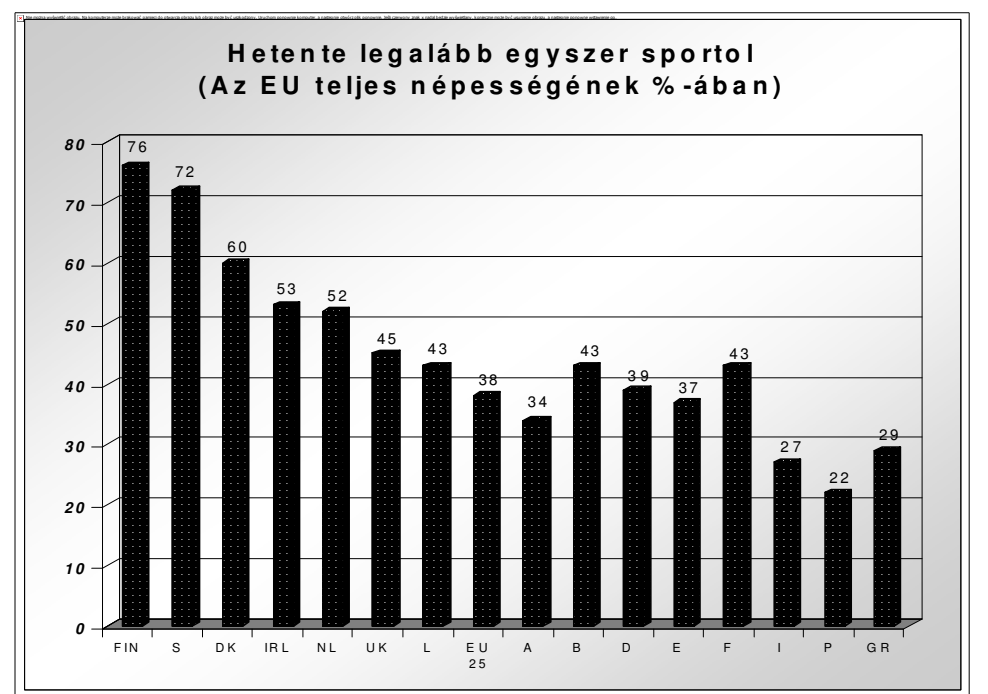

Figure 1. European citizens doing sport at least once a week by country (\%) Source: Citizens of the European Union and sport (2004), Special Eurobarometer 213. 
Scandinavians remain in 2004 the most sportingly active citizens of the European Union. The vast majority of sporting activity takes place in amateur structures. Professional sport is of growing importance and contributes equally to the societal role of sport. In addition to improving the health of European citizens, sport has an educational dimension and plays a social, cultural and recreational role. The societal role of sport also has the potential to strengthen the Union's external relations (White Paper on Sport 2007). Europeans in the north tend to do more sport than those in the south. In Finland and in Sweden the share of those engaging in weekly physical activity is $76-72 \%$, whereas in Denmark $60 \%$ do sport at least once a week. In Italy this proportion is only $27 \%$. Among the new member States we can observe a rather high number of sportsmen, above the European average, in Malta (42\%), Cyprus and Slovenia (43\%). However, this proportion tends to be significantly lower in some southern countries, such as Portugal (22\%) and several new member States such as Hungary $(20 \%)$.

In spite of the fact that this Europe of sport still seems to have a vague explanation and definition, it still possesses similar characteristics: the dynamics of sports associations remains its fundamental component and its essential engine. Even if state and community interventions have had a growing tendency in Europe, the sports sector at large remains governed and organized according to its own rules, defined mainly on the international level, thus ensuring a great extent of autonomy. These aspects in themselves would be enough to explain the slow recognition of sport as a social phenomenon in the process of European integration.

Besides, the treatment of these sports-related questions does correspond to the principle of subsidiarity, which states that every competence has to be dealt with at the most appropriate level of decision-making.

Naturally though, public policy in sport does not exclusively concern people and groups dealing directly with sport but also those indirectly affected by "public actions". All in all, a few million teachers, instructors and volunteers are engaged in fostering sport in the European Community.

Originally destined to provide health and pleasure, sport is now a first-class economic factor due to its extremely increasing media coverage.

European sport public policy would then have both substance and a social sphere of action. In the following, the more critical parts of the definition are to be analyzed.

Regarding the coercion factor, we have to recognise that both in its functional and organizational aspects, sports can be identified most easily on the scope of the nation-state level. On the other hand, the institutional system is rather heterogeneous, and the level of state intervention shows considerable differences. European sport as a concept first appeared at the intergovernmental level through the activity of the Council of Europe, having surpassed national framework and competence. But the only organization possessing supranational institutions hindering state sovereignty is the European Union, where the factor of coercion could be exercised on the European level. In present times, life and activities, and the deepening of European integration, everyone obliges sports decision-makers to respect European norms. No country could exert effective individual pressure on international sports federations which are already too powerful. There is no other power and authority but the EU to make them follow the general objectives of their respective members. In other words, the EU has the only authority of a legal nature on the European level. Perhaps it is not a coincidence that the headquarters of the biggest international sports associations can be found in states which are not EU Members, and the above mentioned factor will not prevail.

Since the 1970s the Court of Justice has applied EU Treaty rules binding EU member states to 
the activities of private regulators as well ${ }^{2}$. In the Bosman ruling of 1995, the Court specified that: "Article 48 not only applies to the action of public authorities but extends also to rules of any other nature" ${ }^{3}$. Consequently, the EU institutions have treated sports governing bodies in a similar manner to "public authorities", meaning that their private rules do not escape the application of the fundamental principles of the EU Treaty (in particular, regarding the free movement of labour). Even so, the EU has been less willing to recognise that sports governing bodies must enjoy a margin of appreciationto enable them to exercise their regulatory functions in a meaningful sense ${ }^{4}$.

In the case of the EU even the expression "sport" is nowhere to be found in the Treaties, so theoretically there is no direct community competence to speak of. Despite the fact that in the European Union the management and organization of sport belong to the sphere of influence of member states and the national and international sports organizations, sport is affected by numerous community policies, and if it appears in an economic context, then it is regulated by community law. Thus the field is directly affected by regulations of competition and the market.

It is true, however, that in the annex of the Amsterdam Treaty (adopted on 2 October 1997), Presidents and Prime Ministers adopted a declaration related to sport which "underlines the social importance of sport, and in particular, its role to strengthen identity and create union between people".

Following the European Commission's Report to the Helsinki European Council (December 1999) and in the light of the development of certain discussions, such as those related to the transfer of football players, the Nice European Council (7-10 December 2000) also adopted a declaration which urges the EU and its Member States to respect the specificities of sport and to consult with their federations. The Treaty of Nice deals with the question as above, but fails to embed it into the body of the Treaty.

Nevertheless, the declaration is not obligatory from a legal point of view, but only indicates an intention of how to treat certain issues. In other words, the concrete actions to take are not discussed and no legal guarantee which sport would need is provided in the document. However, it is still significant considering the fact that in the Treaty of Nice, the European prime ministers recognized the specific nature of sport. "Consequently, the debate is no longer about whether sport has a specific nature: it is about the practical measures that need to be implemented to take account of this specific nature as a matter of European law." (Independent European Sport Review 2006)

The Lisbon Treaty would modify the effectual EU and EC Treaties; however, as opposed to the Constitution, it would not replace them. The objective of the Lisbon Treaty, which was signed by European heads of government on 13 December 2007, is to make Europe more democratic, more transparent and more efficient. The treaty was designed to establish the Europe of rights and interests, freedom, solidarity and security, and to create the opportunity for Europe to emerge as a global actor more effectively. And last but not least, it deals with sport as an activity to be supported by the Union. ${ }^{5}$ Therefore, sport still cannot be regarded as a community competence. After all, there is no proper community competence in this sector. But the EU, having a definite power to act, has implicit areas of competence according to the Treaty and concerning sectors such as sport.

Above all, the EU can naturally intervene because of the bias of intergovernmental action. The sports ministers of different Member States have the possibility to meet and define common orientations. Sometimes this leads to important results, as in the case of doping, where the EU

\footnotetext{
${ }^{2}$ Case 36/74, Walrave (1974) ECR 1405 and Case 13/76 Dona v Mantero (1976) ECR 1333.

${ }^{3}$ Case C-415/93, Bosman (1995) para. 82.

${ }^{4}$ Independent European Sport Review 2006, p. 31.

${ }^{5}$ In the 2008 referendum, the Irish rejected the ratification of the Lisbon Treaty.
} 
managed to contribute to the creation of a World Agency. The Commission may issue proposals and reports in this framework, such as the one it has already presented on sports in the EU to the Helsinki Council. Any normative policy can only be mentioned when decision-makers do not give random answers to the arising problems, and if they were held accountable for these decisions.

This is the exact reason why the White Paper on Sport issued by the European Commission is a major step forward. "This White Paper focuses on the societal role of sport, its economic dimension and its organisation in Europe, and on the follow-up that will be given to this initiative. Concrete proposals for further EU action are brought together in an Action Plan named after Pierre de Coubertin which contains activities to be implemented or supported by the Commission."

Since White Papers are documents which make recommendations for communal action on a given area, they cannot be regarded as legal sources, or obligations in any sense.

Besides, sport is governed by the general rules of the Treaty. Today, the European construction shows a rising influence on sports activities. At the same time, the liberal principles of the free movement of people, goods and services may find multiple applications in the field of sport. The rules of the treaty apply to sport as to all other sectors. Nevertheless, it is rather hard to define such a normative line which proves the existence of European public policy in sport; known legal cases connected to sport do not prove the fulfilment of these criteria.

The Lisbon Treaty lifts sport into the circle of activities which can be supported by the Union. Although it does not go further, it still provides an adequate legal basis for establishing funds and inviting tenders for sport projects in the next budgetary period. However, the logic of these actions is much less clear.

The most debatable criterion is the programme. "Une politique publique européenne se présente sous forme d'un programme d'action européenne dans un secteur de la société ou dans un espace géographique" (Meny and Thoening 1989, p. 130). Public policy is not characterized by isolated activities. Behind deeds, behind activities there has to be a general framework, into which they can integrate. If not even a medium-term European sport concept for different actors exists to comply with, then not only is there no European sports policy to speak of, but sport cannot play the role of the uniting, identity-forming force either, which would be its natural role in an integrating Europe, or "to strengthen identity and create union between people".

On sport matters, it is the Council of Europe which made efforts to develop a humanist sport policy with a wide cooperation among member states that clearly opposes the primarily economic concept of sport in the EU.

The EU almost entirely devotes itself to the dark side of sports - doping, stadium violence, broadcasting rights, ticket-selling etc. To polarize a little, we could say that what tabloid papers deal with will, sooner or later, appear on the EU agenda. It is to be noted, however, that the "2004 European year of education through sports" was a pioneer initiative.

It is the Council of Europe which has a real sports concept. The ideas appearing in the European Sports Charter and Code of Sport Ethics serve as bases upon which the future of European sports is to be built. The White Paper on Sport and the Pierre de Coubertin Action Plan are in accordance with this, although it is less clear who will realize these initiatives, from what source, and who is to monitor the process.

\footnotetext{
${ }^{6}$ http://ec.europa.eu/sport/white-paper/whitepaper8_en.htm\#2
} 


\section{Conclusion}

Analyzing European public policy related to sports, we have to draw the conclusion that the aforementioned criteria are only partly met by European sports policy. To exercise a public policy one needs literal and significant budgetary resources, and these are not to be found from the European institutions.

The number of administrative personnel delegated to deal with sports at European level is far lower than the staff of a national Sports Ministry. Nevertheless, the realization of the Pierre de Coubertin Action Plan included in the White Paper, and the ratification of the Lisbon Treaty can serve as a good starting point so that sport becomes included in the public policy of the European Union. However, this calls for a legislative process serving for the realization of the recommendations of the White Paper. In addition to this, a concrete agenda should also be elaborated, which would provide a basis for a long-term action plan. It should be stipulated what human, material and other resources the Union is planning to mobilize when realizing the action plan, and what guarantees are incorporated in the system, etc. It should be defined how much this is going to cost, and what should be integrated into the budget of the EU. There is a need for measurable results and corresponding indicators. Furthermore, the programmes do not only concern one institution, they delegate tasks to ministries of education, health care, and environment, and institutions of the Union, as well as those of the member states, and sport organizations. Therefore, it should be clarified what the concrete tasks of the different actors are in the realization of the White Paper, and also what the administrative burdens are. If these problems are all solved, then we could indeed talk about a European public policy.

Until then, international sports associations have to comply with EU legal norms and requirements. National sport authorities have to consider the declarations and recommendations of the Council of Europe. Sports professionals have to find the necessary elbow-room in this situation to be able to assist the development of European sports. It is not an easy task but very challenging. Good luck to them!

\section{REFERENCES}

Citizens of the European Union and sport (2004). Special Eurobarometer 213. At http://ec.europa.eu/public_opinion/archives/ebs/ebs_213_report_en.pdf

Code of Sport Ethics (2001). Council of Europe.

European Sports Charter (1992; 2001). Council of Europe.

Independent European Sport Review (2006). Report by: José Luis Arnaut, Executive Summary. October 2006.

Meny, Y., Thoening, J.C. (1989). Politiques Publiques. Editions Presses Universitaires de France.

Presidential conclusions at the Nice meeting of the European Council. Appendix IV. 7-9 December, 2000.

Waele, J.M., Husting, A. (2000). Sport et Union Européenne. Bruxelles: Edition de l'Université de Bruxelles.

White Paper on Sport (2007). Brussels: European Commission. http://ec.europa.eu/sport/whitepaper/whitepaper8_en.htm\# 